obstructed, having a residual of $5 \mathrm{ml}$ urine. Diabetes had been diagnosed before her diversion, and she had had glycosuria in her bladder urine. One of the diabetic patients (case 1) had been reported on previously ${ }^{2}$ and had had ketoacidosis without glycosuria. He did not have conduit glycosuria on any other occasion (though this may reflect good diabetic control). Under the conditions of this experiment, however, his loop did not remove glucose and it is therefore difficult to explain how this clinical problem arose. Glycosuria had been noted on two occasions before diversion, suggesting that he had a normal renal threshold for glucose. It is possible that during ketoacidosis, altered urinary ionic concentrations secondary to poor renal function enhanced reabsorption of glucose or raised the renal threshold. ${ }^{413}$

The ability of a conduit to absorb glucose would depend in part on the integrity of its mucosa. We did not obtain biopsy samples of these loops, but in a series of excised loops we consistently found mucosal atrophy (paper in preparation). Interestingly, both cases described by McGournan occurred early after diversion, perhaps before any metaplasia had occurred in the conduit mucosa. ${ }^{1}$

In this experiment we looked only at absorption of glucose under one set of conditions (albeit reasonably physiological ones). Further study with other ions in the solution is needed to understand fully the problems of the diabetic urinary conduit. On the basis of our work so far we conclude that urinary conduits in non-diabetic patients do not absorb glucose. In diabetics it is possible that sufficient glucose may be absorbed to abolish glycosuria: this point should be checked in individual patients before advice is given on routine diabetic management. When screening patients with diversion for diabetes random measurement of blood glucose concentrations must be performed. The method that we have described would be suitable for the study of other conduit urine constituents.
We are grateful to Dr D F Evered, of Chelsea College, and to Dr G A Nelstrop, consultant physician, for their advice and help. Mrs A Stainton kindly prepared the glucose and phenol red solutions.

\section{References}

${ }^{1}$ McGournan RCM. Glucose absorption from ileal loops. $\mathrm{Br}$ Med $\mathcal{F}$ 1977; ii :932.

${ }^{2}$ Onwubalili JK. Overt diabetes mellitus without glycosuria in a patient with cutaneous ureteroiliostomy. $\mathrm{Br} M$ Med $\mathcal{F} 1982 ; 284: 1836$.

${ }^{3}$ McLeod GM, French AB, Good CJ, Wright FS. Gastrointestinal absorption and biliary excretion of phenol red in man. $f \mathrm{Lab}$ Clin Med $1968 ; 71: 192-5$.

${ }^{4}$ Modigliani R, Rambaud JC, Bernier JJ. Method of intraluminal perfusion of the human small intestine. Digestion 1973;9:176-92.

${ }^{5}$ French AB, Brown IF, Good CJ, McLeod GM. Comparison of phenol red and polyethylene glycol as non-absorbable markers for the study of intestinal absorption in humans. Am $\mathcal{F}$ Dig Dis 1968;13:558-64.

6 Janknegt RA. Absorption of urine in jejunum, ileum and sigmoid loops. Urol Int 1967;22:435-45.

Demos MP. Radioactive electrolyte absorption studies of small bowel: comparison of different segments for use in urinary diversion. $\mathcal{F}$ Urol $1962 ; 88: 638-43$.

${ }^{8}$ Davidson JN, Garry RK. The absorption of monosaccharides from the large intestine of the rat under urethane anaesthetic. $\mathcal{F}$ Physiol (Lond) $1939 ; 96: 172-5$.

${ }^{9}$ Curry FS, Bargen JA. Studies on absorption and excretion in segments of the colon of man. Surg Gynecol Obstet 1935;60:667-74.

${ }^{10}$ Dretler SP. The pathogenesis of urinary tract calculi occurring after ileal conduit diversion. I. Clinical study. II. Conduit study. III. Prevention. f Urol 1973;109:204-9.

${ }^{11}$ Ganong WF. Digestion and absorbtion. In: Ganong WF, ed. Review of medical physiology. 8th ed. California: Lange Medical, 1977:352-9.

12 Baker RA, Searle GW, Nunn AS. Glucose and sorbose absorption at various levels of rat small intestine. Am F Physiol 1961;200:301-3.

${ }^{13}$ Manning AS, McMullan JM, Evered DF. Influence of calcium ions on uptake of sugars by rat small intestine in vitro. Biochem Soc Trans $1978 ; 6: 914-6$.

(Accepted 24 August 1983)

\title{
Hyposensitisation to wasp venom in six hours
}

\author{
J C VAN DER ZWAN, J FLINTERMAN， I G JANKOWSKI, J A M KERCKHAERT
}

\begin{abstract}
Eleven patients with a history of anaphylaxis, positive reactions to skin tests, and specific IgE antibody to wasp venom underwent hyposensitisation in a six hour procedure. No general reactions occurred. Complement activation and proteinuria could not be shown.

The patterns of specific IgE, IgG1, and IgG4 were as described in other procedures-namely, IgE increased sharply and then decreased; IgG1 and IgG4 increased steadily and then decreased-but increase and decrease came earlier.

Challenge by a stinging insect at least four weeks after treatment proved complete protection. The skin reactivity two years later showed an unpredictable pattern.
\end{abstract}

\section{Introduction}

Anaphylaxis to venom by insects of the order Hymenoptera is common and leads to several deaths each year. ${ }^{1}$ Fear of fatal reactions and a consequent change in lifestyle follows non-fatal systemic reaction to the venom. ${ }^{2}$ Since the first procedure of hyposensitisation with pure venom was described in $1974,{ }^{3}$ details of many different methods have been published. ${ }^{4-7}$ Insect venoms and venom proteins have been used in the diagnosis of insect sting allergy by direct skin testing. ${ }^{4}$ Analysis by means of the radioallergosorbent test for specific IgE antibody has been performed. ${ }^{8}$

We studied 11 patients at risk of developing anaphylaxis to wasp venom. Hyposensitisation with the maximum dose was achieved within six hours. Complement activation as well as proteinuria were looked for. The different titres of total IgE and specific IgE, IgG1, and IgG4 against wasp venom were studied over seven months.

\section{Patients and methods}

Ten women and one man fulfilled the criteria suggested by Lichtenstein ${ }^{9}$ : an early general reaction, positive reaction to skin test with wasp venom, and the presence of specific IgE in the serum
J FLINTERMAN, MD, dermatologist

J A M KERCKHAERT, MD, immunologist 
Clinical and laboratory data of 11 patients with anaphylactic reactions to wasp venom who underwent hyposensitisation

\begin{tabular}{|c|c|c|c|c|c|c|c|c|c|c|}
\hline \multirow{2}{*}{$\begin{array}{l}\text { Case } \\
\text { No }\end{array}$} & \multirow{2}{*}{$\begin{array}{c}\text { Age } \\
\text { (years) }\end{array}$} & \multirow[b]{2}{*}{ Sex } & \multicolumn{2}{|c|}{ Skin threshold ( $\mu$ g venom)* } & \multirow{2}{*}{$\begin{array}{l}\text { Specific IgE } \\
(\% \text { binding })\end{array}$} & \multicolumn{4}{|c|}{ General reactions } & \multirow{2}{*}{$\begin{array}{l}\text { Challenge } \\
\text { (inadvertent } \\
\text { in two years) }\end{array}$} \\
\hline & & & Before treatment & During treatment & & Erythema & Urticaria & $\begin{array}{l}\text { Quincke's } \\
\text { oedema }\end{array}$ & Shock & \\
\hline $\begin{array}{r}1 \\
2 \\
3 \\
4 \\
5 \\
6 \\
7 \\
8 \\
9 \\
10 \\
11\end{array}$ & $\begin{array}{l}33 \\
42 \\
39 \\
27 \\
36 \\
42 \\
40 \\
46 \\
56 \\
37 \\
33\end{array}$ & $\begin{array}{l}F \\
F \\
F \\
F \\
F \\
F \\
F \\
F \\
F \\
F \\
M\end{array}$ & $\begin{array}{l}0.0001 \\
0.001 \\
0.001 \\
0.01 \\
0.00001 \\
0.01 \\
0.01 \\
0.0001 \\
0.01 \\
0.01 \\
0.01\end{array}$ & $\begin{array}{l}0.0001 \\
0.1 \\
0.01 \\
0.1 \\
0.001 \\
0.01 \\
0.00001 \\
10.0 \\
0.01 \\
0.01 \\
0.01\end{array}$ & $\begin{array}{l}27 \cdot 4 \\
24 \cdot 1 \\
20 \cdot 1 \\
17 \cdot 2 \\
25 \cdot 1 \\
16 \cdot 1 \\
6 \cdot 2 \\
23.5 \\
12 \cdot 1 \\
13 \cdot 6 \\
12 \cdot 8\end{array}$ & $\begin{array}{l}+ \\
+ \\
+ \\
+ \\
+ \\
+ \\
+ \\
+ \\
=\end{array}$ & $\begin{array}{l} \pm \\
\pm \\
\pm \\
+ \\
\pm \\
\pm \\
\pm \\
\pm \\
-\end{array}$ & $\begin{array}{l}+ \\
+ \\
+ \\
+ \\
+ \\
+ \\
+ \\
+ \\
+ \\
+\end{array}$ & $\begin{array}{l}- \\
+ \\
- \\
+ \\
+ \\
+ \\
+ \\
+ \\
+\end{array}$ & $\begin{array}{l}\overline{-} \\
\overline{0} \\
\overline{0} \\
0 \\
\overline{0} \\
0 \\
-\end{array}$ \\
\hline
\end{tabular}

-Amount of venom necessary to provoke a reaction.

$-=$ No reaction. $+=$ Positive reaction. $0=$ No inadvertent challenge.

(table). An intracutaneous skin test was considered to have given a positive reaction at a titre of $0.01 \mathrm{mg} / 1$ or less. Total $\mathrm{IgE}$ and specific IgE, IgG1, and IgG4 were estimated with a radioallergosorbent test. The titre of specific IgG1 and IgG4 was expressed in percentages of a $\mathrm{Clq}$ reference serum and specific IgE in \% binding. Estimations of $\mathrm{Clq}, \mathrm{C} 3$, and $\mathrm{C} 4$ were performed according to the Mancini procedure, ${ }^{10}$ and haemolytic component $\left(\mathrm{CH}_{50}\right)$ was estimated with a haemolysis test. ${ }^{11}$

The patients were admitted to the intensive care unit for 24 hours. An intravenous needle was inserted, and clemastine and adrenaline made ready for use. Pulse rate, blood pressure, and temperature were measured every half hour. The initial dose of venom was a factor of 10 measured every half hour. The threshold for the venom in the skin-that is, amount of venom that provoked a reaction-was estimated, and the initial dose of venom was a factor 10 below the threshold. The venom was injected subcutaneously in both upper legs. The amount of venom was increased 10 fold up to $1 \mu \mathrm{g}$. The next doses, of $5,20,30,60$, and $100 \mu \mathrm{g}$, were all given with a 30 minute interval. Blood samples were collected before and half an hour after the last injection for estimation of $\mathrm{C} 1 \mathrm{q}, \mathrm{C} 3, \mathrm{C} 4$, and $\mathrm{CH}_{50}$, and urine samples were taken for detection of proteinuria.

Booster injections were given in the outpatient department with

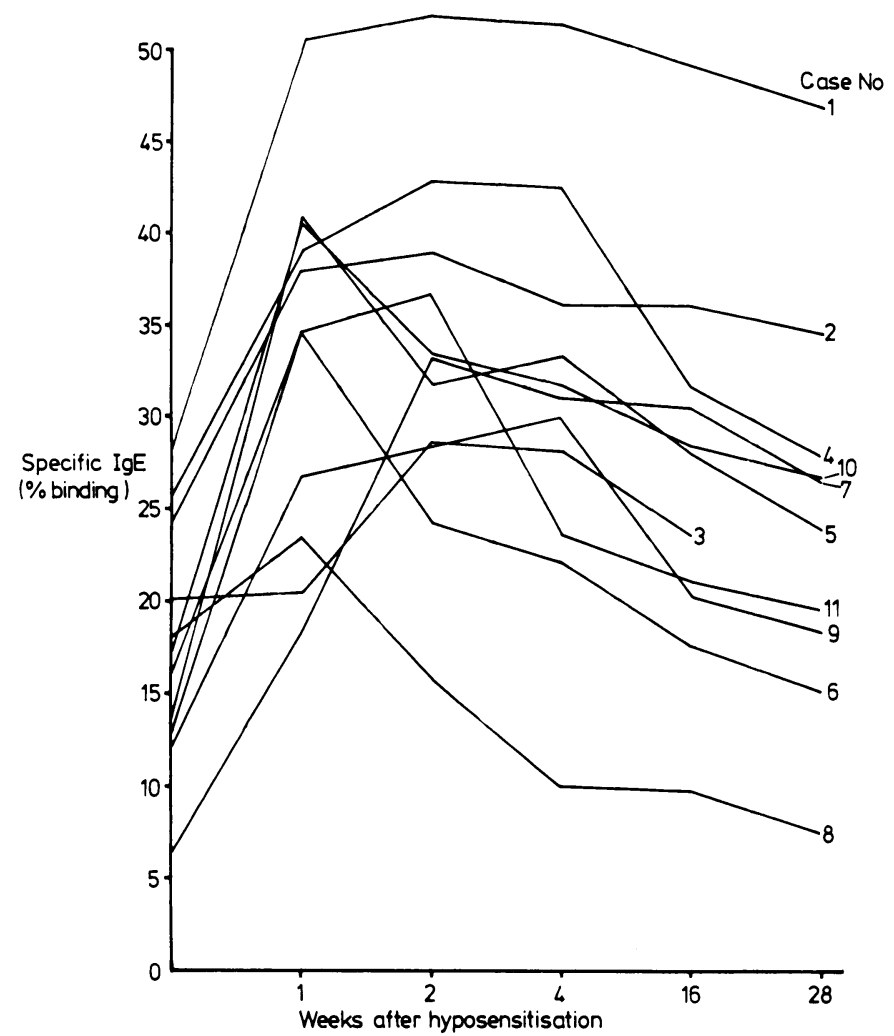

FIG 1 - Titre of specific IgE (as $\%$ binding) against wasp venom at $0,1,2$, 4,16 , and 28 weeks after hyposensitisation. $(n=11$.)

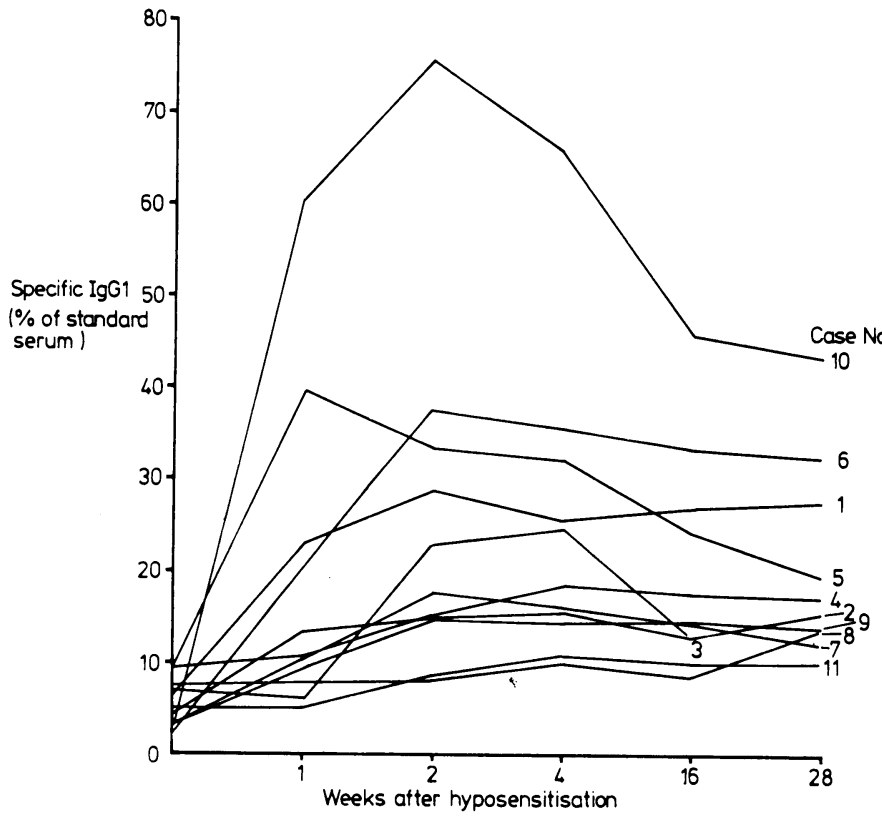

FIG 2-Titre of specific IgGl (as \% of standard serum) against wasp venom at $0,1,2,4,16$, and 28 weeks after hyposensitisation. $(n=11$.)

a dose of $100 \mu \mathrm{g}$ at seven, 14 , and 28 days after hyposensitisation and then every four weeks. All patients were rechallenged by a wasp sting, at least four weeks after the start of the hyposensitisation A living wasp was pressed on the underarm, and the sting was left in situ for at least 20 seconds. The same precautions were taken at the time of challenge as for the hyposensitisation procedure.

\section{Results}

There were no general reactions during hyposensitisation in spite of the fact that the total dose given in six hours was equivalent to nearly four stings. All the patients had a considerable local swelling with redness and pain at the site of injection; this reaction started two to six hours after the first dose and decreased after 24-36 hours. No fever developed. Neither booster injections nor the provocation induced general reactions. It was remarkable that most stings remained in the skin after removal of the insect, as the small barbed hooks present in the wasp sting are less pronounced than in the honeybee.

There was no change in the level of $\mathrm{C} 1 \mathrm{q}, \mathrm{C} 3, \mathrm{C} 4$, or $\mathrm{CH}_{50}$. Proteinuria was not detected. The specific IgE decreased after a quick initial rise. There was a fast rise of specific IgG1 and IgG4 (figs 1-3).

Skin tests were repeated two years later, while the booster injections were still continued every six weeks. Six patients had the same skin threshold, in four it lowered, and in one patient it increased sharply. We rechallenged this patient with a living wasp, but only a local reaction occurred. Five other patients received wasp stings inadvertently but again had only a local reaction. 


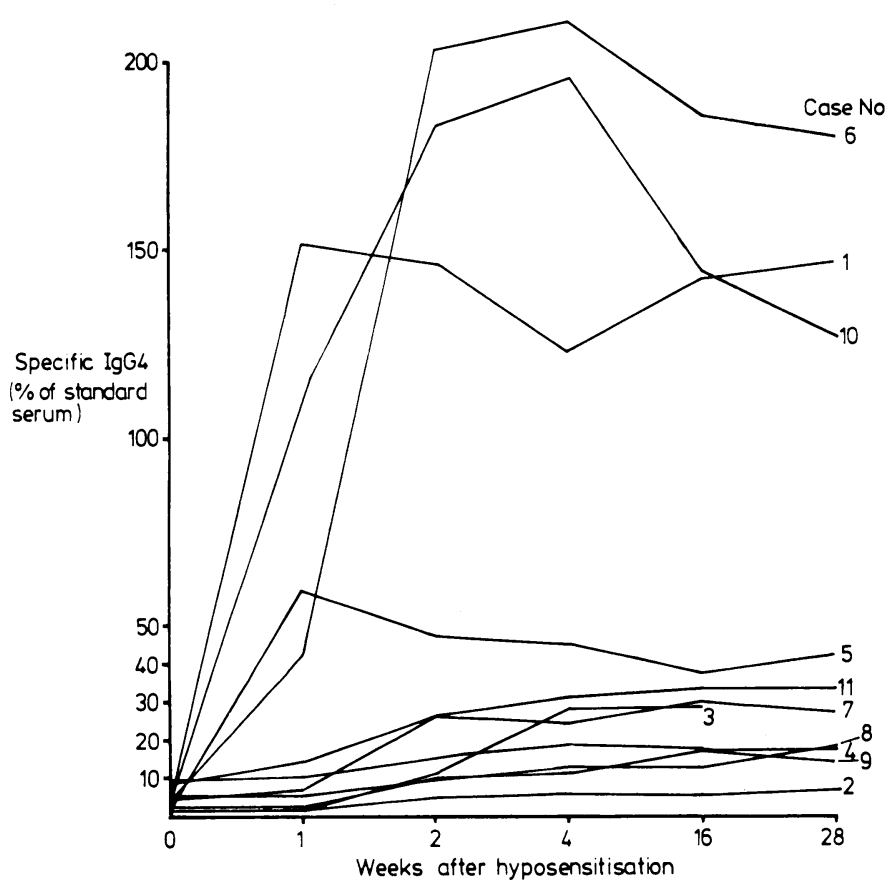

FIG 3-Titre of specific IgG4 (as \% of standard serum) against wasp venom at $0,1,2,4,16$, and 28 weeks after hyposensitisation. $(n=11$.)

\section{Discussion}

Protection against a general reaction after a sting with wasp venom could be presumed from the titres of specific IgG1 and IgG4, which increased and then decreased after one to four weeks. IgE also increased and then decreased after one to two weeks. This pattern has been described before. ${ }^{612} 13$ The rise of antibody titres varied considerably between patients as has also been described. ${ }^{5}$ ?

In this series no general reactions occurred. We have now treated 60 patients with anaphylaxis for both wasp and bee venom in the same way and only in three of them was a slight general reaction noted. It is difficult to explain how the procedure can be performed in six hours without provoking any serious general reaction. Because of the cross linking of the receptors at the surface of the mast cell when antigen (allergen) is bound by the fixed IgE, the dose of antigen could be the crucial point. When the dose is too low, cross linking is not possible nor can the mast cells be activated, resulting in tolerance. ${ }^{14}$ Alternatively, the production of $\mathrm{IgG}$ antibody may have a crucial role and antigen binding by IgG may block the access of antigen to IgE. ${ }^{15}$

From our results it can be seen that during treatment there is a steady increase of serum titre for both IgGl and IgG4, with a decrease thereafter for both subclasses. The appearance of IgG antibodies is not the only responsible factor, however, because Urbanek et al showed the absence of correlation between IgG antibody titre to bee venom and the degree of clinical protection.? Also, in patients who failed to respond to immunotherapy, a significant rise in their serum IgG antibody titre conferred no obvious protection. ${ }^{16}$ Another cause of the unresponsiveness of the immune system to the challenge antigen may be selective depletion of recirculating lymphocytes. ${ }^{17}$ Whether this mechanism enables hyposensitisation to be performed in six hours or less without general reactions is unknown.

The pattern of the skin threshold during the hyposensitisation is unpredictable. That five of the 11 patients were stung again within two years gives an indication of the presumed risks. In conclusion, a fast hyposensitisation procedure in cases of anaphylaxis to wasp venom has proved effective without serious side effects.
We thank R C Aalberse and J C J Clemens for performing the tests for immunoglobulins, $\mathrm{E} J$ Hensen for commenting on the paper, and $\mathrm{Ms} S$ van Elst for typing the manuscript.

\section{References}

${ }^{1}$ Parish HM. Deaths from bites and stings of venomous animals and insects in the United States. Archives of Internal Medicine 1959;104:198-207.

2 Settipane GA, Newstead GJ, Boyd GK. Frequency of Hymenoptera allergy in an atopic and normal population. $\mathcal{f}$ Allergy Clin Immunol $1972 ; 50: 146-50$

${ }^{3}$ Lichtenstein LM, Valentine MD, Sobotka AK. A case for treatment in anaphylactic sensitivity to Hymenoptera sting. $N$ Engl f Med 1974; 290:1223-7.

4 Hunt KJ, Martin MD, Sobotka AK, Benton AW, Amodio FJ, Lichtenstein LM. A controlled trial of immunotherapy in insect hypersensitivity. $N$ Engl f Med 1978;299:157-61.

5 Yunginger JW, Paul BR, Jones RT, Santrach PJ. Rush venom immunotherapy program for honeybee sting sensitivity. $\mathcal{F}$ Allergy Clin Immunol $1979 ; 63: 340-7$

' Golden DB, Valentine MD, Kagey-Sobotka A, Lichtenstein LM. Regimens of Hymenoptera Venom Immunotherapy. Ann Intern Med $1980 ; 92: 620-4$.

7 Urbanec R, Forster J, Karitsky D. Rush hyposensitisation with pure bee venom; one year prospective study in children. In: Oehling $A$, ed. Proceedings of the International Congress of Allergy and Applied Immunology X. New York, 1980:333.

${ }^{8}$ Sobotka AK, Adkinson NF, Valentine MD. IgE studies of patients with insect hypersensitivity. Fed Proc 1976;35:673-81.

${ }^{9}$ Lichtenstein $\mathrm{LM}$, Valentine $\mathrm{MD}$, Sobotka $\mathrm{AK}$. Insect allergy: the state of art. $\mathcal{F}$ Allergy Clin Immunol 1979;64:5-12.

${ }^{10}$ Hudson L, Hay FC. Practical immunology. Oxford: Blackwell Scientific Publications, 1976:138.

${ }^{11}$ Hudson L, Hay FC. Practical immunology. Oxford: Blackwell Scientific Publications, 1976:134.

12 Sobotka AK, Adkinson NF, Valentine MD, Lichtenstein LM. Allergy to insect sting. IV. Diagnosis by radioallergosorbent test. $f$ Immunol $1978 ; 121: 2477-84$.

${ }^{13}$ Sobotka AK, Valentine MD, Iskizaka K, Lichtenstein LM. Measurement of IgG blocking antibodies. Development and application of a radioimmunoassay. F Immunol 1976;117:84-90.

14 Feldman M, Howard JC, Desaymard C. Role of antigen structure in discrimination between tolerance immunity by B-cells. Transplantation Reviews $1975 ; 23: 78-97$.

15 Van der Zwan JC, Aalberse RC, Van Erven A, De Monchy JGR, Reerink Brongers $\mathrm{E}$. Antibody response to bee venom in beekeepers in relation to their clinical data. Allergol Immunopathol (Leipz) 1980;8:277-8.

16 Yunginger W, Santrach BA. Treatment failures following honeybee venom immunotherapy: use of passive immunization. $\mathcal{f}$ Allergy Clin Immunol $1979 ; 63: 179$.

17 Hopkins J, McConnell I, Lachman PJ. Specific selection of antigenreactive lymphocytes into antigenically stimulated lymphnodes in sheep. f Exp Med 1981;153:706.

ONE HUNDRED YEARS AGO SIR,-In order to be more secure, if possible, from contamination, I send my household dirty linen to a steam laundry (Battersea Park). A short time ago, my little boy, aged $6 \frac{1}{2}$, had a slight attack of German measles. His nurse, by my directions, saturated the whole of the linen, used by him, in "sanitas" before leaving the nursery, and made a remark in the washing-book as to the child's ailment (German measles). A few days later, a regular lecture from the manager of the establishment was written to my wife, for neglect in not sending for their special cart, etc. To my astonishment, a charge of $15 \mathrm{~s}$ was then made for disinfecting the linen of the whole house. I laud the precaution as most praiseworthy; but if a charge of $15 \mathrm{~s}$ is to be made for every time a child has German measles, is it the proper way to get parents to report cases of even small-pox or scarlet fever? On my remonstrance regarding the charge, I am to be allowed a deduction of onehalf, because I am a medical man. In my opinion, the sooner this sort of extra charge is done away with, the sooner we shall get at the truth regarding infectious diseases. It would be, I think, of great importance if the BRITISH MEDICAL JouRNAL would lay down some plain rules for disinfecting clothing efficiently and at a cheap rate for all laundries, and also instructions for parents as to precautions regarding linen, etc, and so help to lessen the punishment on parents. - Yours faithfully, Cosmo G LoGIE, MD, late Surgeon-Major, Royal Horse Guards. (British Medical fournal 1883; ; :798.) 